\title{
Antimicrobial Susceptibility of Flavobacterium psychrophilum Isolated from Rainbow Trout (Oncorhynchus mykiss)
}

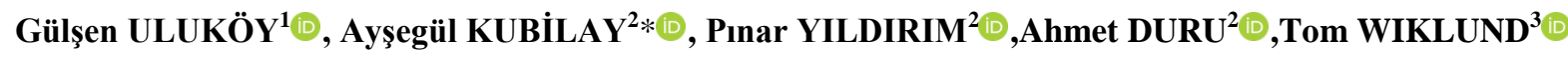 \\ ${ }^{1}$ Department of Aquaculture, Diseases Division, Faculty of Fisheries, Muğla Sitkı Koçman University, Muğla- \\ Turkey, 48000 \\ ${ }^{2}$ Department of Aquaculture, Faculty of Fisheries, Isparta University of Applied Sciences, Isparta, Turkey, \\ 32200 \\ ${ }^{3}$ Laboratory of Aquatic Pathobiology, Environmental and Marine Biology, Åbo Akademi University, Åbo, \\ Finland, 20520
}

*Corresponding Author: aysegulkubilay@isparta.edu.tr

Received 07 April 2021; Accepted 19 July 2021; Release date 01 December 2021.

How to Cite: Uluköy, G., Kubilay, A., Yıldırım, P., Duru A., \& Wiklund, T. (2021). Antimicrobial susceptibility of Flavobacterium psychrophilum isolated from Rainbow Trout (Oncorhynchus mykiss). Acta Aquatica Turcica, 17(4), 541547. https://doi.org/10.22392/actaquatr.910309

\begin{abstract}
This study was conducted to determine antibiotic susceptibility of Flavobacterium psychrophilum isolated in diseased rainbow trout (Oncorhynchus mykiss) from two hatcheries in the Mediterranean region of Turkey. The samples were taken from the kidney and spleen for bacteriology from rainbow trout juveniles (weight $0.7-1 \mathrm{~g}$ ) in April and isolates obtained on tryptone yeast extract salts (TYES) agar medium at $15^{\circ} \mathrm{C}$ for 72 hours. Fourteen isolates were identified as $F$. psychrophilum using biochemical, physiological, and morphological characteristics and API ZYM test. Antibiotic sensitivities of the isolates were determined by the disc diffusion method on TYES agar, and the results were evaluated according to CLSI standards. Only one isolate from each hatchery was used for the antibiogram test. Both isolates were sensitive to amoxicillin/clavulanic acid 2:1, penicillin, nitrofurantoin, florfenicol, amoxicillin, clindamycin, chloramphenicol, ampicillin, doxycycline, streptomycin, and erythromycin; resistant to sulfadiazine, sulfamethoxazole/trimethoprim, oxolinic acid, vancomycin, trimethoprim/sulfadiazine, gentamicin, kanamycin, nalidixic acid, oxacillin, enrofloxacin, flumequine, tobramycin. The results show that isolating $F$. psychrophilum and performing the antimicrobial susceptibility testing is important issue in disease control.
\end{abstract}

Keywords: antibiotics resistance, RTFS, hatcheries, rainbow trout fry.

Gökkuşağı Alabalıklarından (Oncorhynchus mykiss) İzole Edilen Flavobacterium psychrophilum İzolatlarının Antimikrobiyal Duyarlıı̆̆ı

Özet

$\mathrm{Bu}$ çalışma, Türkiye'nin Akdeniz bölgesindeki iki kuluçkahaneden temin edilen hasta gökkuşağı alabalıklarından (Oncorhynchus mykiss) izole edilen Flavobacterium psychrophilum'un antibiyotik duyarlılığını belirlemek amaciyla yapılmıştır. Nisan ayında hasta gökkuşağı alabalığı yavrularının (ağırlığı 1-2 g) böbrek ve dalağından alınan örneklerlemelerde tryptone yeast extract salts (TYES) agar besiyerine ekim yapılarak $15^{\circ} \mathrm{C}$ de 72 saat inkübe edilerek izolatlar elde edilmiştir. Biyokimyasal, fizyolojik ve morfolojik özellikler ve API ZYM testi kullanılarak 14 izolat $F$. psychrophilum olarak tanımlanmıştır. İzolatların antibiyotik duyarlılıkları TYES agarda disk difüzyon yöntemi ile belirlenmiş, sonuçlar CLSI standartlarına göre değerlendirilmiştir. Her kuluçkahaneden sadece bir izolat antibiyogram testi için kullanılmıştır. Her iki izolat da amoksisilin / klavulanik asit 2:1, penisilin, nitrofurantoin, florfenikol, amoksisilin, klindamisin, kloramfenikol, ampisilin, doksisiklin, streptomisin ve eritromisine duyarlı; sülfadiazin, sülfametoksazol / trimetoprim, oksolinik asit, vankomisin, trimetoprim / sülfadiazin, gentamisin, kanamisin, nalidiksik asit, oksasilin, enrofloksasin, flumequine, tobramisine dirençlidir. Sonuçlar, F. psychrophilum'un izole edilerek antimikrobiyal duyarlılık testinin yapılmasının hastalıkla mücadele de önemli olduğunu göstermektedir.

Anahtar Kelimeler: Antibiyotik direnci, RTFS, kuluçkahane, yavru gökkuşağı alabalığı.

\section{INTRODUCTION}

The Gram-negative bacterium, Flavobacterium psychrophilum, causing bacterial cold water disease (BCWD) and rainbow trout fry syndrome (RTFS) has been seen in mostly freshwater salmonids. During the last twenty years, RTFS has become one of the most serious bacterial diseases 
in rainbow trout (Oncorhynchus mykiss, Walbaum) hatcheries in many parts of Europe. Outbreaks of diseases caused by F. psychrophilum are treated with antibiotics. A limited number of commercial vaccines are currently available in Chile and Norway but they are not suitable for fry fish (Madetoja, 2002; Gómez et al., 2014; Boyacioglu et al., 2015; Hoare et al., 2017). The only course of action which occurs in fry is the antibiotic treatment which has led to increased levels of antibiotic resistance (Henríquez-Núñez et al., 2012, Wahli and Madsen, 2018, Saticioglu et al., 2019).

In recent years, RTFS is causing mortality rates between $10 \%$ and $30 \%$. Also, the cumulative mortality rate of fries found to be up to $70 \%$ in Turkey (Gultepe and Tanrikul, 2006; Kubilay et al., 2009; Özcan and Sarıyyüpoğlu, 2014; Boyacioglu et al., 2015). Previously, oxytetracycline and chlortetracycline were the only antimicrobial agents licensed for use in aquaculture. Currently, the use of oxytetracycline has dropped about $55 \%$ and $75 \%$ to treat flavobacteriosis disease in fish farms in the western Aegean region (Kum et al., 2008; Boyacioglu and Akar 2012). Nowadays, oxolinic acid and florfenicol antibiotics are licensed for use in fish. Today, florfenicol is the drug of choice. Until now, the resistance of $F$. psychrophilum to florfenicol has scarcely been reported in Turkey (Kum et al., 2008; Saticioglu et al., 2019).

Several studies carried out in different countries have also shown the differences in resistance profiles among $F$. psychrophilum isolates. Valdebenito and Avendano-Herrera (2009) found that $F$. psychrophilum isolates from Chile were resistant to sulphamethoxazole+trimethoprim but highly sensitive to amoxicillin. In Denmark, F. psychrophilum isolates were resistant to amoxicillin (11.6\%), oxolinic acid (65.9\%), oxytetracycline (67.7\%), and sulphamethoxazole+trimethoprim (98.2\%) (Bruun et al. 2000). In another study, Del Cerro et al. (2010) found that $F$. psychrophilum isolates originating from Spain were found resistant to oxytetracycline. Özcan and Sarieyyüpoğlu (2013), evaluated the antibacterial susceptibility of resistance profiles strains and found that strains sensitive to oxytetracycline, florfenicol, enrofloxacin, and ciprofloxacin. Among the studies, it is seen that much more variations on the antimicrobial resistance profile of $F$. psychrophilum that is the causative agent of RTFS.

This study aimed to determine the antimicrobial susceptibility of $F$. psychrophilum isolated from sick rainbow trout fries from two hatcheries in the Mediterranean region of Turkey.

\section{MATERIALS and METHODS}

\section{Samples Bacterial Isolation and Identification}

Fish samples were obtained from two hatcheries (F1 and G1) in the Mediterranean region of Turkey. Tissue samples for bacteriology were taken from rainbow trout fries which showed signs of diseases in April. Fish weighted 0.7-1 g and a total of 14 fish were examined. The samples were collected from the kidney and spleen and streaked onto ryptone yeast extract salts (TYES) agar (Holt et al., 1994). Agar plates were incubated at $15^{\circ} \mathrm{C}$ for 72 hours. Isolates were identified by using biochemical, physiological, and morphological characteristics by following the guidelines for the diagnosis of fish diseases and the international and national guidelines for animal welfare (OIE, 2003; Buller, 2004; Austin and Austin, 2016). and a rapid identification kit by using API ZYM test (Austin and Austin, 2016).

\section{Antimicrobial Susceptibility Testing}

Antimicrobial sensitivities of the isolates were determined by the disc diffusion method on TYES agar. Only one isolate from each hatchery $(\mathrm{F} 1, \mathrm{G} 1)$ was used for the antibiogram test. Antibiotic discs (Oxoid, England) (Total 24) were used for determining the resistance profiles. The results were evaluated according to guidelines of the Clinical and Laboratory Standards Institute (CLSI,_2014), Briefly, TYES broth was used to prepare bacterial suspensions. The turbidity of suspensions was adjusted to McFarland 0.5 and $100 \mu \mathrm{l}$ aliquots were spread over TYES agar surface. Antibiotic discs were placed on the surface of the inoculated agar plates and the plates were incubated at $15^{\circ} \mathrm{C}$ for 5 days. After the incubation period, the inhibition zone diameters were measured and the results were evaluated according to the CLSI, 2014 and Van Vliet et al., 2017.

\section{RESULT and DISCUSSION}

In this study, sick fish samples (14 fish) were obtained from two hatcheries (F1 and G1) in April from farms where the water temperature at $(\mathrm{F} 1)$ was $8{ }^{\circ} \mathrm{C}$ and another hatchery $(\mathrm{G} 1)$ had $13{ }^{\circ} \mathrm{C}$ and the fries infected with RTFS showed signs of diseases such as dorsal fin erosion, darkening body, and 
splenomegaly (Figure 1). The result of the rapid identification test API ZYM on the isolates (F1 and G1) showed the pathogen as F. psychrophilum (Figure 2).
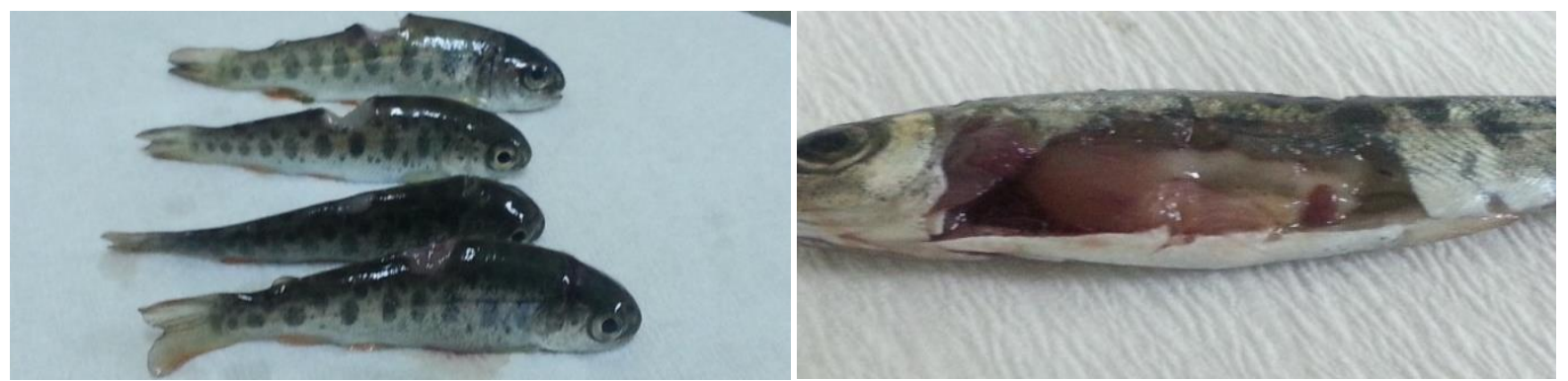

Figure 1. Dorsal fin deep erosion (left) and splenomegaly (right) in rainbow trout fries with RTFS

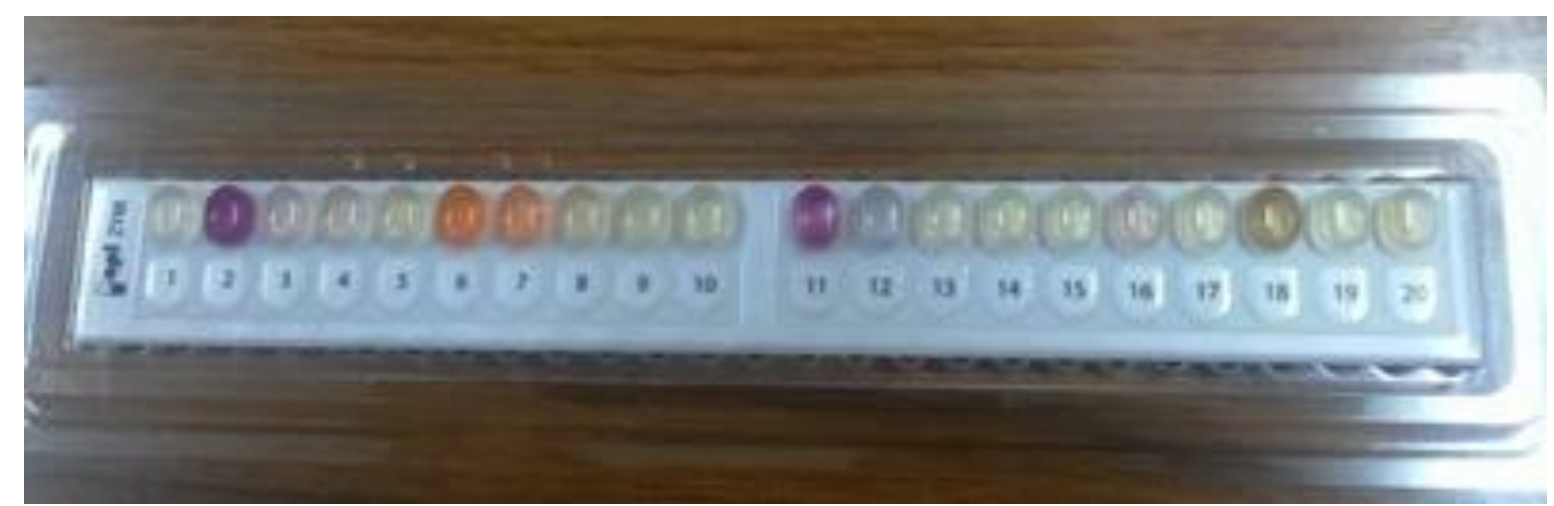

Figure 2. Result of API ZYM test for F. psychrophilum

The improvement of antimicrobial resistance by $F$. psychrophilum could be a concern since outbreaks regularly require the utilize of antimicrobials. During outbreaks, $F$. psychrophilum strains (Figure 3) were identified in fries of rainbow trout in the hatcheries. Both isolates from rainbow trout were sensitive to amoxicillin/clavulanic acid 2:1, penicillin, nitrofurantoin, florfenicol, amoxicillin, clindamycin, chloramphenicol, ampicillin, doxycycline, streptomycin, erythromycin, and tetracycline. The isolates were resistant to sulfadiazine, oxolinic acid, vancomycin, nalidixic acid, oxacillin, and tobramycin. While the examined isolates were sensitive to florfenicol, they were resistant to sulfonamides. The results indicate that antimicrobial susceptibility testing of $F$. psychrophilum is an important issue to be able to fight RTFS disease outbreaks.
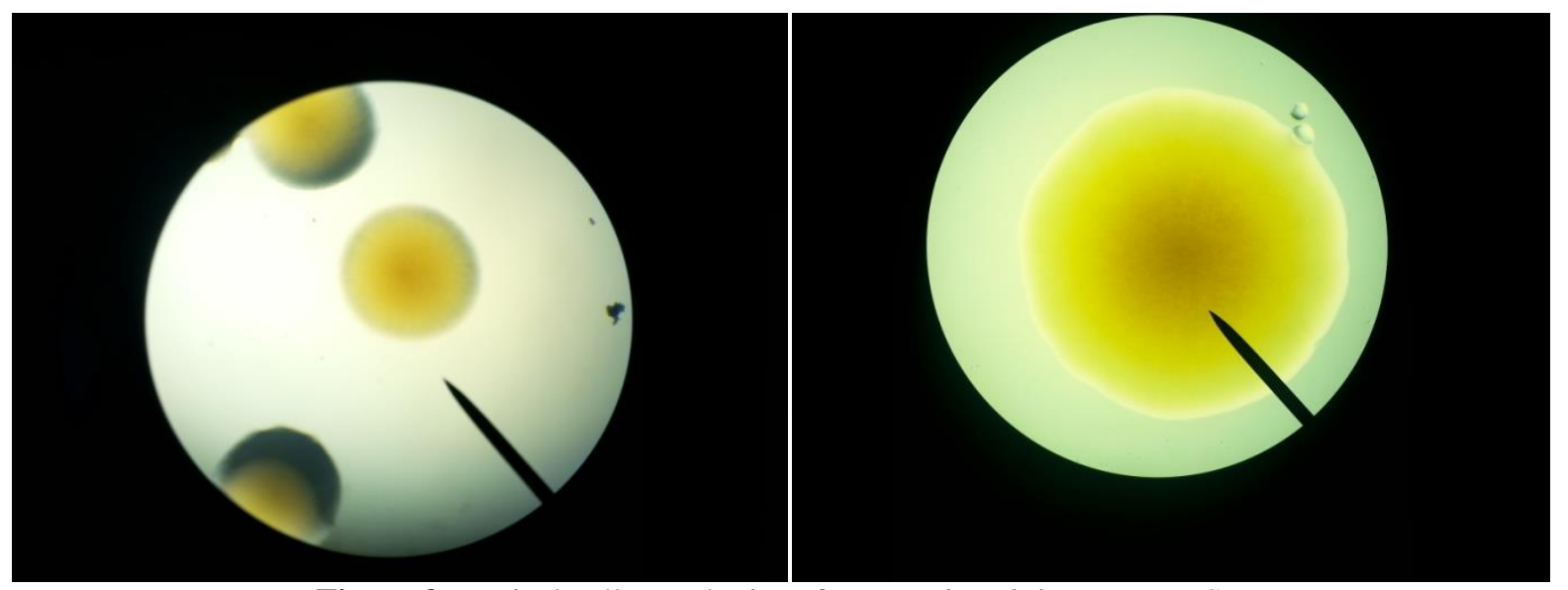

Figure 3. Typical yellow colonies of $F$. psychrophilum on TYES agar

The results of the antibiotic susceptibility test in both F.psychrophilum isolates were found to be susceptible to 12 , intermediate to 3 , and resistant to 5 out of 24 examined antibiotics (Table 1). While, isolate F1 showed resistance against trimethoprim/sulfadiazine and kanamycin, isolate G1 was 
susceptible to these antibiotics (Figure 4). The reason for it might be the developing resistance of the bacteria to these antibiotics in the hatchery F1. Saticioglu et al. (2019) reported that all isolates of $F$. psychrophilum were susceptible to amoxicillin and florfenicol.

Table 1. Antibiotic susceptibility profiles of $F$. psychrophilum isolates

\begin{tabular}{lll}
\hline \hline Antibiotic Disc & Isolate, F1 & Isolate, G1 \\
\hline Sulfadiazine $(25 \mu \mathrm{g})$ & $\mathrm{R}(0 \mathrm{~mm})$ & $\mathrm{R}(0 \mathrm{~mm})$ \\
Florfenicol $(30 \mu \mathrm{g})$ & $\mathrm{S}(53 \mathrm{~mm})$ & $\mathrm{S}(57 \mathrm{~mm})$ \\
Sulphamethoxazole/Trimethoprim $(25 \mu \mathrm{g})$ & $\mathrm{I}(10 \mathrm{~mm})$ & $\mathrm{I}(14 \mathrm{~mm})$ \\
Chloramphenicol $(30 \mu \mathrm{g})$ & $\mathrm{S}(47 \mathrm{~mm})$ & $\mathrm{S}(43 \mathrm{~mm})$ \\
Ampicillin $(10 \mu \mathrm{g})$ & $\mathrm{S}(38 \mathrm{~mm})$ & $\mathrm{S}(39 \mathrm{~mm})$ \\
Erythromycin $(15 \mu \mathrm{g})$ & $\mathrm{S}(22 \mathrm{~mm})$ & $\mathrm{S}(24 \mathrm{~mm})$ \\
Oxolinic acid $(2 \mu \mathrm{g})$ & $\mathrm{R}(0 \mathrm{~mm})$ & $\mathrm{R}(0 \mathrm{~mm})$ \\
Streptomycin $(10 \mu \mathrm{g})$ & $\mathrm{S}(28 \mathrm{~mm})$ & $\mathrm{S}(35 \mathrm{~mm})$ \\
Vancomycin $(30 \mu \mathrm{g})$ & $\mathrm{R}(0 \mathrm{~mm})$ & $\mathrm{R}(13 \mathrm{~mm})$ \\
Trimethoprim/ Sulfadiazine $(30 \mu \mathrm{g})$ & $\mathrm{R}(0 \mathrm{~mm})$ & $\mathrm{S}(25 \mathrm{~mm})$ \\
Gentamycin $(10 \mu \mathrm{g})$ & $\mathrm{I}(13 \mathrm{~mm})$ & $\mathrm{S}(15 \mathrm{~mm})$ \\
Nitrofurantoin $(300 \mu \mathrm{g})$ & $\mathrm{S}(57 \mathrm{~mm})$ & $\mathrm{S}(53 \mathrm{~mm})$ \\
Doxycycline $(30 \mu \mathrm{g})$ & $\mathrm{S}(41 \mathrm{~mm})$ & $\mathrm{S}(34 \mathrm{~mm})$ \\
Kanamycin $(30 \mu \mathrm{g})$ & $\mathrm{R}(0 \mathrm{~mm})$ & $\mathrm{S}(20 \mathrm{~mm})$ \\
Nalidixic Acid $(30 \mu \mathrm{g})$ & $\mathrm{R}(0 \mathrm{~mm})$ & $\mathrm{R}(0 \mathrm{~mm})$ \\
Amoxicillin $(25 \mu \mathrm{g})$ & $\mathrm{S}(53 \mathrm{~mm})$ & $\mathrm{S}(55 \mathrm{~mm})$ \\
Penicillin $(10 \mu \mathrm{g})$ & $\mathrm{S}(57 \mathrm{~mm})$ & $\mathrm{S}(60 \mathrm{~mm})$ \\
Clindamycin $(2 \mu \mathrm{g})$ & $\mathrm{S}(47 \mathrm{~mm})$ & $\mathrm{S}(44 \mathrm{~mm})$ \\
Oxacillin $(1 \mu \mathrm{g})$ & $\mathrm{R}(0 \mathrm{~mm})$ & $\mathrm{R}(0 \mathrm{~mm})$ \\
Enrofloxacin $(5 \mu \mathrm{g})$ & $\mathrm{I}(15 \mathrm{~mm})$ & $\mathrm{I}(20 \mathrm{~mm})$ \\
Flumequin $(30 \mu \mathrm{g})$ & $\mathrm{I}(20 \mathrm{~mm})$ & $\mathrm{I}(10 \mathrm{~mm})$ \\
Tetracycline $(30 \mu \mathrm{g})$ & $\mathrm{S}(38 \mathrm{~mm})$ & $\mathrm{S}(30 \mathrm{~mm})$ \\
Tobramycin $(30 \mu \mathrm{g})$ & $\mathrm{R}(0 \mathrm{~mm})$ & $\mathrm{R}(0 \mathrm{~mm})$ \\
Amoxicillin/Clavulanic acid $2: 1(30 \mu \mathrm{g})$ & $\mathrm{S}(60 \mathrm{~mm})$ & $\mathrm{S}(60 \mathrm{~mm})$ \\
\hline \hline
\end{tabular}

R, Resistance; S, Susceptible; I, Intermediate

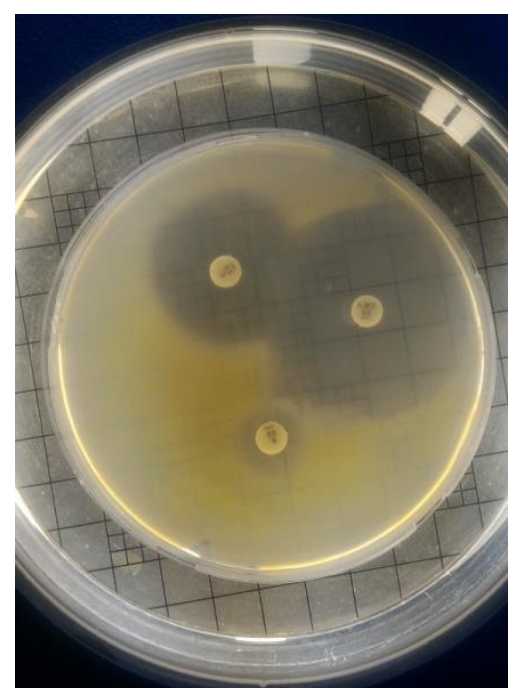

Figure 4. Susceptibility test of F. psychrophilum against Amoxicillin/ Clavulanic acid 2:1 (S), Chloramphenicol (S) and Oxacillin (R) 
Many studies have been performed to determine the antibiotic resistance profiles of $F$. psychrophilum in various regions of Turkey and quite variable profiles have been observed. Balta (1997) recorded that $F$. psychrophilum was sensitive to nitrofurans but resistant to flumequine, sulphonamides, and oxolinic acid. Diler et al. (2003) have reported that two F. psychrophilum isolates were sensitive to amoxicillin-clavulanic acid, oxytetracycline, and gentamicin but resistant to trimethoprim. In another study, five $F$. psychrophilum isolates from rainbow trout farms in eastern Anatolia were reported to be sensitive to oxytetracycline, erythromycin, gentamicin, nitrofuran, and amoxicillin-clavulanic acid, but resistant to chloramphenicol and penicillin (İspir et al., 2004). Boyacioglu (2007) reported that a total of $20 \mathrm{~F}$. psychrophilum strains isolated from an outbreak in Muğla province were resistant to ampicillin (95\%), sulphamethoxazole (95\%), erythromycin (45\%), and oxytetracycline (20\%) but sensitive to enrofloxacin (100\%). In these studies, different techniques were used to evaluate antibiotic resistance profiles. In the Mediterranean region, $13 \mathrm{~F}$. psychrophilum strains isolated from different outbreaks were resistant to enrofloxacin (23\%), amoxicillin (46.2\%), erythromycin (61.5\%), kanamycin (30.8\%), cefoperazone (46.2\%), and oxolinic acid (53.8\%) (Didinen et al., 2005). Durmaz et al. (2012), showed that $F$. psychrophilum isolates were resistant to neomycin, ampicillin, amoxicillin, and kanamycin. Furthermore, $80 \%, 40 \%, 20 \%$, and $20 \%$ of these isolates were resistant to erythromycin, cefoperazone, oxolinic acid, and sulphamethaxazole+trimetoprim, respectively. However, all the strains were $100 \%$ sensitive to oxytetracycline and enrofloxacin. It was considered that these variable resistance profiles may be due to the widespread use of different antibiotics or to differences among the strains. Several studies carried out in different countries have also shown the differences in resistance profiles among $F$. psychrophilum isolates. Valdebenito and Avendano-Herrera (2009) found that $F$. psychrophilum isolates from Chile were resistant to sulphamethoxazole+trimethoprim but highly sensitive to amoxicillin. $387 \mathrm{~F}$. psychrophilum isolates were resistant to amoxicillin (11.6\%), oxolinic acid (65.9\%), oxytetracycline (67.7\%), and sulphamethoxazole+trimethoprim (98.2\%) in Denmark (Bruun et al., 2000). In another study, Del Cerro et al. (2010) found that 25 F. psychrophilum isolates originating from Spain were found resistant to oxytetracycline (>80\%). The findings of the present study were not in agreement with those mentioned above. However, Rangdale et al. (1997), reported identical results to the current study concerning sensitivity to enrofloxacin. These differences in antibiotic resistance profiles of $F$. psychrophilum might be due to the use of different techniques or isolated strain variations. Ngo et al. (2018) determined the antimicrobial susceptibilities of $133 \mathrm{~F}$. psychrophilum strains. They found a high categorical agreement between the classifications of the isolates for florfenicol (100\%), oxytetracycline (93\%), and oxolinic acid (99\%). Mwega et al. (2020), reported that assessing the antimicrobial susceptibility of Flavobacteriaceae family members isolated from Nile tilapia (Oreochromis niloticus). The antimicrobial susceptibility of 67 Flavobacteriaceae isolates originating mainly from ponds and Lake Victoria against 19 antimicrobial agents was determined. Overall, most isolates were found to be susceptible to enrofloxacin (97\%). Ö̈zcan and Sarıeyyüpoğlu (2013), found $F$. psychrophilum strains were sensitive to oxytetracycline, florfenicol, enrofloxacin, and ciprofloxacin. These results are similar to our results for florfenicol (sensitive) but different for enrofloxacin (intermediate).

In conclusion, $F$. psychrophilum was isolated from commercial rainbow trout hatcheries in the Mediterranean region of Turkey. To control $F$. psychrophilum infections and to ensure the rational use of antibiotics, it is important to run the antibiotic susceptibility tests by using standard methods (CLSI, 2014). It is concluded that the most critical point is $F$. psychrophilum antimicrobial resistance patterns should be determined to treat the disease in farms in each region and country.

\section{ACKNOWLEDGEMENTS}

The author P.Y. is supported by Turkish Council of Higher Education (YOK) 100/2000 PhD scholarship program.

\section{REFERENCES}

Austin, B. and A. Austin (2016). Bacterial fish pathogens: Disease in farmed and wild fish. 6th ed.; Publisher: Springer-Praxis, Goldalming.

Balta, F. (1997). Kültürü yapılan alabalıklarda (Oncorhynchus mykiss) görülen Flexibacter psychrophila enfeksiyonu. IX. Ulusal Su Ürünleri Sempozyumu. 17-19 Eylül 1997. Eğirdir/Isparta. 641-648. 
Bruun, M.S., Schmidt, A.S., Madsen, L., \& Dalsgaard, I. (2000). Antimicrobial resistance patterns in Danish isolates of Flalobacterium psychrophilum. Aquaculture, 187, 201-212.

Boyacioglu, M., (2007). Gökkuşağı alabalıklarında (Oncorhynchus Mykıss) RTFS’ye (Rainbow Trout Fry Syndrome) neden olan Flavobacterıum Psychrophilum etkeninin izolasyonu ve antibakteriyel sağaltım seçeneğinin belirlenmesi. T.C. Adnan Menderes Üniversitesi, Sağlık Bilimleri Enstitüsü, Farmakoloji ve Toksikoloji Anabilim Dalı, Aydın.

Boyacioglu, M., \& Akar, F. (2012). Isolation of Flavobacterium psychrophilum causing rainbow trout fry syndrome and determination of an effective antibacterial treatment in rainbow trout (Oncorhynchus mykiss) fry. Journal of The Faculty of Veterinary Medicine, Kafkas University; 18: 197-203.

Boyacioglu, M., Kum, C., Kirkan, Ş., Sekkin, S., Parin, U., Karademir, Ü., \& Akar, F. (2015). Comparison of in vitro and in vivo antibacterial efficacy for the control of Flavobacterium psychrophilum in rainbow trout (Oncorhynchus mykiss) fry: the first genotypical evidence in West Aegean region of Turkey. Turkish Journal of Veterinary and Animal Sciences, 39(3), 314-321.

Buller, N., 2004. Bacteria from fish and other aquatic animals: A practical dentification manual. Publisher: CABI Publishing, UK.

CLSI (2014). Performance Standards for Antimicrobial Susceptibility Testing of Bacteria Isolated from Aquatic Animals; Second Informational Supplement. CLSI document VET03/04-S2. Clinical and Laboratory Standards Institute, Wayne, PA.

Del Cerro, A., Marquez, I., \& Prieto, J.M. (2010). Genetic diversity and antimicrobial resistance of Flavobacterium psychrophilum isolated from cultured rainbow trout, Onchorynchus mykiss (Walbaum), in Spain. Journal of Fish Diseases, 33,285-291.

Didinen, B.I., Diler, O., Ekici, S., \& Altun, S. (2005). Flavobacterium psychrophilum izolatlarının teşhisinde API ZYM kullanımı ve ATB VET ile antimikrobiyal duyarlılığın belirlenmesi. SDÜ Ĕ̈irdir Su Ürünleri Fakültesi Dergisi, 1, 64-70.

Diler, Ö., Altun, S., \& Işıklı, B.I. (2003). Kültürü yapılan gökkuşağı alabalığı (Oncorhynchus mykiss)'ndan izole edilen Flavobacterium psychrophilum'un fenotipik karakterleri. SD ̈̈ Fen Bilimleri Enstitüsü Dergisi, 7, $1-8$

Durmaz, Y., Onuk, E. E., \& Ciftci, A. (2012). Investigation of the presence and antibiotic susceptibilities of Flavobacterium psychrophilum in rainbow trout farms (Oncorhynchus mykiss Walbaum, 1792) in The Middle and Eastern Black Sea Regions of Turkey. Ankara Üniversitesi Veteriner Fakultesi Dergisi,59, 141-146.

Gómez, E., Mendez, J., Cascales, D., \& Guijarro, J.A. (2014). Flavobacterium psychrophilum vaccine development: A difficult task. Microbial Biotechnology. 7:414-423.

Gultepe, N., \& Tanrikul, T. T. (2006). Treatment methods of Flavobacterium psychrophilum: cause of rainbow trout fry syndrome (RFTS) and bacterial cold water disease (BCWD) in Turkey. Journal of Fisheries International, 1(2-4), 102-105.

Henríquez-Núñez, H., Evrard, O., Kronvall, G., \& Avendaño-Herrera, R. (2012). Antimicrobial susceptibility and plasmid profiles of Flavobacterium psychrophilum strains isolated in Chile. Aquaculture, 354, 38-44.

Holt, J. G., Krieg, N. R., Sneath, P. A., Staley, J. T., \& Williams, S. T. (1994). Bergey's Manual of Determinate Bacteriology. 9th edn. Williams \& Wilkins, Baltimore, USA.

Hoare, R., Ngo, T. P., Bartie, K. L., \& Adams, A. (2017). Efficacy of a polyvalent immersion vaccine against Flavobacterium psychrophilum and evaluation of immune response to vaccination in rainbow trout fry (Onchorynchus mykiss L.). Veterinary Research, 48(1), 1-13.

İspir, Ü., Şeker, E., Sağlam, N., \& Dörücü, M. (2004). Doğu Anadolu Bölgesi’nde bazı Gökkuşağı alabalığ1 (Oncorhynchus mykiss) işletmelerinde görülen Flavobacterium psychrophilum enfeksiyonunun araştırılması. Fırat Üniversitesi Fen ve Mühendislik Bilimleri Dergisi, 16(4), 718-724.

Kubilay, A., Altun, S., Didinen, B.I., Ekici, S., \& Diler, O. (2009). Isolation of Flavobacterium psychrophilum in farmed rainbow trout (Oncorhynchus mykiss). Journal of The Faculty of Veterinary Medicine, Kafkas University; 15: 709-715 (in Turkish with English abstract).

Kum, C., Kirkan, S., Sekkin, S., Akar, F., \& Boyacioglu, M. (2008). Comparison of in vitro antimicrobial susceptibility in Flavobacterium psychrophilum isolated from rainbow trout fry. Journal of Aquatic Animal Health, 20(4), 245-251.

Madetoja, J. (2002). Flavobacterium psycrophilum: characterisation, experimental transmission and ocuurence in fish and fish farming enviroments. Academic Dissertation, Finland, 1-37.

Mwega, E., Chengula, A., Colquhoun, D., Mutoloki, S., Mdegela, R., Evensen, Ø., \& Wasteson, Y. (2020). Antimicrobial susceptibility of Flavobacteriaceae isolates from Nile Tilapia (Oreochromis niloticus) in Tanzania. African Journal of Microbiology Research, 14(1), 42-50.

Ngo, T. P., Smith, P., Bartie, K. L., Thompson, K. D., Verner-Jeffreys, D. W., Hoare, R., \& Adams, A. (2018). Antimicrobial susceptibility of Flavobacterium psychrophilum isolates from the United Kingdom. Journal of Fish Diseases, 41(2), 309-320. 
OIE (Office International des Epizooties). (2003). Manual of diagnostic tests for aquatic animals, 4th edn. Office International des Epizooties.

Özcan, M., \& Sarieyyüpoğlu, M. (2013). Elazı ğ ilindeki bazı alabalık işletmelerinde izole edilen Flavobacterium psychrophilum'un antibakteriyel duyarlılıklarının incelenmesi. Yunus Araştırma Bülteni, 2013(2) 11-19.

Özcan, M., \& Sarieyyupoglu, M. (2014). Identification and Investigation of Phenotypic and Genotypic Characteristics of Flavobacterium psychrophilum in Fry Rainbow Trouts (Oncorhynchus mykiss) in Some Trout. International Journal of Sciences. 3 (3) 24-34.

Rangdale, R.E., Richards, R.H., Alderman, D.J. (1997). Minimum inhibitory concentrations of selected antimicrobial compounds against Flavobacterium psychrophilum the causal agent of rainbow trout fry syndrome (RTFS). Aquaculture, 158, 193-201.

Saticioglu, I. B., Duman, M., Smith, P., Wiklund, T., \& Altun, S. (2019). Antimicrobial resistance and resistance genes in Flavobacterium psychrophilum isolates from Turkey. Aquaculture, 512, 734293.

Wahli, T., \& Madsen, L. (2018). Flavobacteria, a never ending threat for fish: a review. Current Clinical Microbiology Reports, 5(1), 26-37.

Valdebenito S., \& Avendano-Herrera, R. (2009). Phenotypic, serological, and genetic characterization of Flavobacterium psychrophilum strains isolated from salmonids in Chile. Journal of Fish Diseases, 32, 321-333.

Van Vliet, D., Loch, T. P., Smith, P., \& Faisal, M. (2017). Antimicrobial susceptibilities of Favobacterium psychrophilum isolates from the Great Lakes Basin, Michigan. Microbial Drug Resistance, 23(6), 791798. 